\title{
Surface-Related Toxicity of Polystyrene Beads to Nematodes and the Role of Food Availability
}

Mueller, Marie-Theres; Fueser, Hendrik; Trac, Ngoc Lam; Mayer, Philipp; Traunspurger, Walter; Höss, Sebastian

\section{Published in:}

Environmental Science and Technology

Link to article, DOI:

10.1021/acs.est.9b06583

Publication date:

2020

Document Version

Publisher's PDF, also known as Version of record

Link back to DTU Orbit

Citation $(A P A)$ :

Mueller, M-T., Fueser, H., Trac, N. L., Mayer, P., Traunspurger, W., \& Höss, S. (2020). Surface-Related Toxicity of Polystyrene Beads to Nematodes and the Role of Food Availability. Environmental Science and Technology, 54(3), 1790-1798. https://doi.org/10.1021/acs.est.9b06583

\section{General rights}

Copyright and moral rights for the publications made accessible in the public portal are retained by the authors and/or other copyright owners and it is a condition of accessing publications that users recognise and abide by the legal requirements associated with these rights.

- Users may download and print one copy of any publication from the public portal for the purpose of private study or research.

- You may not further distribute the material or use it for any profit-making activity or commercial gain

- You may freely distribute the URL identifying the publication in the public portal 


\title{
Surface-Related Toxicity of Polystyrene Beads to Nematodes and the Role of Food Availability
}

\author{
Marie-Theres Mueller, Hendrik Fueser, Lam Ngoc Trac, Philipp Mayer, Walter Traunspurger, \\ and Sebastian Höss
}

Cite This: Environ. Sci. Technol. 2020, 54, 1790-1798

Read Online

\section{ACCESS | Lill Metrics \& More | 回 Article Recommendations ｜（） Supporting Information}

ABSTRACT: Microplastics released into freshwaters from anthropogenic sources settle in the sediments, where they may pose an environmental threat to benthic organisms. However, few studies have considered the ecotoxicological hazard of microplastic particles for nematodes, one of the most abundant taxa of the benthic meiofauna. This study investigated the toxic effects of polystyrene (PS) beads $(0.1-10.0 \mu \mathrm{m})$ and the underlying mechanisms thereof on the reproduction of the nematode Caenorhabditis elegans. The observed effect of the PS beads on the nematodes correlated well with the total surface area of the beads per volume, with a $50 \%$ inhibition of reproduction at $55.4 \pm 12.9 \mathrm{~cm}^{2} / \mathrm{mL}$, independent of the bead size. The adverse effects were not explained by styrene monomers leaching from the beads because chemical activities of styrene in PS

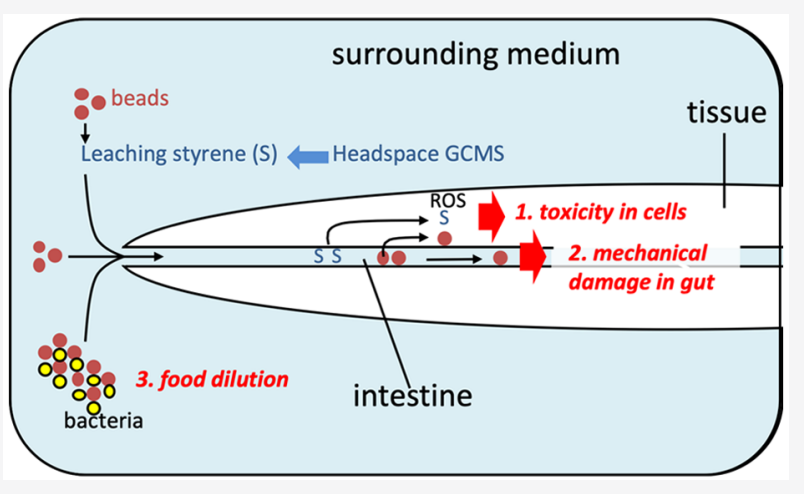
suspensions were well below the toxic levels. However, the observed effects could be related to the bead material because the same-sized silica $\left(\mathrm{SiO}_{2}\right)$ beads had considerably less impact, probably due to their higher specific density. PS and $\mathrm{SiO}_{2}$ beads affected the food availability of $C$. elegans, with greater effects by the PS beads. Our results demonstrate the importance of including indirect food web effects in studies of the ecological risks posed by microplastics.

\section{INTRODUCTION}

Plastic pollution is currently a major environmental concern, ${ }^{1}$ especially in freshwater and marine systems, where large accumulations have been detected. ${ }^{2,3}$ Generally, larger plastic items degrade by chemical, biological, and physical processes into smaller particles, yielding the so-called secondary microplastics, ${ }^{4}$ defined as plastic particles $<5 \mathrm{~mm}$. Microplastics made of polymers with a higher specific density than water, such as polystyrene (PS; $1.05 \mathrm{~g} / \mathrm{cm}^{3}$ ) are transported to the sediment, whereas the settling is enhanced by biofouling processes, increasing the specific density of microplastics. ${ }^{5-9}$ Therefore, PS is one of the most common polymer types for microplastics detected in sediments, where they pose a potential threat to benthic organisms. ${ }^{8}$

Nematodes, belonging to the microscopic fraction of benthic fauna (meiobenthos; $<1 \mathrm{~mm}$ ), are dwelling in fine sediments and account for up to $90 \%$ of the meiobenthic abundance. ${ }^{9-11}$ By connecting lower and higher trophic levels, nematodes occupy a key position in the benthic food web. ${ }^{12-14}$ Moreover, nematodes were shown to ingest considerable numbers of microplastics, thus, being potential vectors for microplastic transport in the benthic food web. ${ }^{15}$ Despite their ecological importance, only few studies focused on the toxicological effects of micro- and nanosized plastics on the nematode Caenorhabditis elegans. ${ }^{16-18}$ The nematode species C. elegans is a model organism used in laboratories worldwide. ${ }^{19}$ Although C. elegans mainly occurs in microbe-rich decaying plant material, $^{20}$ it also can be found in freshwater sediments ${ }^{21}$ and is taxonomically closely related to sediment-dwelling nematode species (e.g., species of Rhabditis). The availability of standardized protocols for testing in water and sediments $^{22,23}$ has resulted in the frequent use of C. elegans in chemical risk assessments, including of nanoparticles. ${ }^{8,24,25}$

For C. elegans, the particle size of microplastics turned out to be more important than the polymer type for explaining toxic effects. ${ }^{17}$ Although it is generally assumed that due to a larger surface area, smaller particles are more toxic than larger ones, ${ }^{26,27}$ Lei et al. ${ }^{17}$ reported that an intermediate size of PS beads $(1.0 \mu \mathrm{m})$ was more toxic than smaller $(0.1 \mu \mathrm{m})$ and larger beads $(5.0 \mu \mathrm{m})$ and caused the highest intestinal damage in C. elegans. On the other hand, nanoplastics $(0.1 \mu \mathrm{m}$ PS beads) might even be translocated to the nematode's reproductive organs, thus, causing transgenerational toxic effects on C. elegans. ${ }^{16}$ Accordingly, it is not clear how effects

Received: October 31, 2019

Revised: December 22, 2019

Accepted: January 2, 2020

Published: January 14, 2020 
of microplastics relate to their size and their ingestion in nematodes and which are the prevailing underlying mechanisms for their adverse effects.

Microplastics that were ingested by $C$. elegans caused oxidative stress by inducing the formation of reactive oxygen species (ROS) in the intestine of C. elegans, leading to inhibitions of the survival rate, body length, and reproduction. ${ }^{16,17}$ However, it could not be excluded that also chemicals leaching from PS nanobeads partly caused the observed effect of the beads. ${ }^{16}$ Some of the effects of microplastics on benthic invertebrates were shown to be associated with the toxic effects of chemicals leaching from the plastics, ${ }^{16,28-31}$ which could be chemical additives (e.g., UV stabilizers), plasticizers, ${ }^{32-34}$ or leached monomers. ${ }^{35-37}$ Toxicity of dissolved leachates can also occur if particles are not ingested by the organisms. Previous studies of PS-polluted sediments have shown that relatively high concentrations of styrene oligomers leached from the particles. ${ }^{38}$ However, to the best of our knowledge, there is no study, where freely dissolved styrene concentrations (i.e., chemical activity) were measured in the PS bead suspensions used for the toxicity tests, in order to investigate the role of styrene leachates for adverse PS effects.

Another mechanism explaining adverse effects of microplastics, apart from any direct toxic effect, might be an interference of the plastic particles with the food of the organism. PS nanoparticles have shown to interact with bacteria by forming agglomerates, thus indirectly affecting $C$. elegans by reducing food accessibility for the nematodes. ${ }^{18}$ It is known that sediment particles in general reduce the availability of food bacteria for $C$. elegans, which is in toxicity tests compensated by providing higher food densities in sediment compared to water exposure. ${ }^{22,23}$ However, it is not clear if plastic particles behave differently than naturally occurring particles, such as silica $\left(\mathrm{SiO}_{2}\right)$ particles.

In the present study, we addressed the abovementioned uncertainties regarding the mechanisms explaining adverse effects of microplastics on nematodes by assessing effects of PS beads with a wide range of diameters on the reproduction of $C$. elegans using a standardized toxicity test (ISO $10872^{22}$ ). We aimed to link the observed effects to (1) the ingestion into the nematodes (presence/absence in the gut), (2) numbers, mass, and surface of the beads, (3) the freely dissolved concentrations of styrene in the PS suspensions, (4) oxidative stress, (5) the food accessibility, and (6) the material of the beads. For this, we generated dose-response curves for the effects of PS beads $(0.1,0.5,1.0,3.0,6.0$, and $10.0 \mu \mathrm{m})$ and $\mathrm{SiO}_{2}$ beads ( 1.0 and $10.0 \mu \mathrm{m})$ on C. elegans and tested the beads at various food densities. Moreover, the response of C. elegans' wild-type strain to PS beads was compared to that of a mutant strain that is hypersensitive to oxidative stress. Finally, freely dissolved styrene concentrations, measured in the PS suspension, were compared to $C$. elegans toxicity thresholds for styrene, which were determined by passive dosing toxicity testing.

We hypothesized that (1) only ingested PS beads can induce adverse effects on C. elegans, (2) toxicity is caused by particlerelated mechanisms (physical effects) rather than by styrene monomer leaching from the beads, and (3) PS beads act as a nonnutritional surrogate of bacterial cells, thus decreasing food availability by hindering food uptake.

\section{MATERIALS AND METHODS}

2.1. Cultivation of the Test Organism. Stock cultures of C. elegans, wild-type (N2 strain) and the mutant strain sod-2 (genotype: sod-2(ok1030), strain: RB1072), were obtained from the Caenorhabditis Genetics Center (University of Minnesota, Minneapolis, MN, USA) and maintained following Stiernagle. ${ }^{39}$ The sod-2 strain has an increased sensitivity to oxidative stress because of a loss of superoxide dismutase (SOD), a detoxifying enzyme that converts oxygen radicals to hydrogen peroxide, which can subsequently be converted to water. The sod-2 mutation results in the inability of this strain to detoxify ROS. ${ }^{40}$ C. elegans was grown on a nematode growth medium $[17 \mathrm{~g}$ of agar/L, $2.5 \mathrm{~g}$ of peptone/L, $3 \mathrm{~g}$ of $\mathrm{NaCl} / \mathrm{L}$ supplemented with $1 \mathrm{~mL}$ of $1 \mathrm{M} \mathrm{CaCl}_{2}, 1 \mathrm{~mL}$ of $1 \mathrm{M} \mathrm{MgSO}_{4}$, $25 \mathrm{~mL}$ of $1 \mathrm{M} \mathrm{KH}_{2} \mathrm{PO}_{4}$ buffer $\mathrm{pH} 6$ (108.3 $\mathrm{g}$ of $\mathrm{KH}_{2} \mathrm{PO}_{4} / \mathrm{L}$ and $35.6 \mathrm{~g}$ of $\mathrm{K}_{2} \mathrm{HPO}_{4} / \mathrm{L}$ ) and $1 \mathrm{~mL}$ of cholesterol solution (5 $\mathrm{mg} / \mathrm{mL}$ in ethanol), added after autoclaving. ${ }^{41}$ Agar plates were seeded with OP50, a uracil-requiring mutant of Escherichia coli that avoids overgrowth of the bacterial lawn, ${ }^{41}$ following standard procedures. ${ }^{39}$ Stock culture plates were stored at $20{ }^{\circ} \mathrm{C}$ in the dark.

2.2. Bacterial Diet. Bacterial suspensions served as the nematode's food source and were prepared according to the ISO guideline $10872 .^{22}$ An E. coli OP50 culture was grown overnight in Luria-Bertani medium ( $1 \%$ peptone, $0.5 \%$ yeast extract, and $1 \% \mathrm{NaCl}$ ) at $37{ }^{\circ} \mathrm{C}$ for $17 \mathrm{~h}$ under constant mixing. The culture was then centrifuged for $20 \mathrm{~min}$ at $2000 \mathrm{~g}$ to harvest the bacterial cells, which were resuspended in M9medium ( $6 \mathrm{~g}$ of $\mathrm{Na}_{2} \mathrm{HPO}_{4}, 3 \mathrm{~g}$ of $\mathrm{KH}_{2} \mathrm{PO}_{4}, 5 \mathrm{~g}$ of $\mathrm{NaCl}$, and $0.25 \mathrm{~g}$ of $\left.\mathrm{MgSO}_{4} \cdot 7 \mathrm{H}_{2} \mathrm{O} / \mathrm{L}\right)$ and washed by a second centrifugation. The bacterial pellet was again resuspended in M9-medium, and the bacterial density was spectrophotometrically determined (Varian Cary 50 Bio UV-visible) based on the optical density $\left(\mathrm{OD}_{600}\right)$ of three subsamples $(1: 20$ dilution) and using a calibration curve $e^{42}$ to achieve a bacterial density twice as high as the intended test concentration of 500 \pm 25 FAU (formazine absorption units; corresponding to $10^{9}$ E. coli cells $/ \mathrm{mL})$. Cholesterol ( $5 \mathrm{mg} / \mathrm{mL}$ in ethanol) was added to obtain a concentration of $2 \mu \mathrm{L} / \mathrm{mL}$.

2.3. PS and $\mathrm{SiO}_{2}$ Beads. Four different stock suspensions of fluorescent beads (diameter: 0.1-3.0 $\mu \mathrm{m}$; excitation maxima: $441 \mathrm{~nm}$; and emission maxima: $485 \mathrm{~nm}$ ) and six stock suspensions of non-fluorescent PS beads (diameters of $0.1,0.5,1.0,3.0,6.0$, and $10.0 \mu \mathrm{m}$ ) were purchased from Polysciences Europe GmbH (Hirschberg, Germany): $0.1 \mu \mathrm{m}$ Fluoresbrite yellow-green microspheres (cat. \#17150) and Polybead microspheres (cat. \#00876); $0.5 \mu \mathrm{m}$ Fluoresbrite yellow-green microspheres (cat. \#17152) and Polybead microspheres (cat. \#07307); $1.0 \mu \mathrm{m}$ Fluoresbrite yellowgreen microspheres (cat. \#17154) and Polybead microspheres (cat. \#07310); $3.0 \mu \mathrm{m}$ Fluoresbrite yellow-green microspheres (cat. \#17155) and Polybead microspheres (cat. \#17134); and $6.0 \mu \mathrm{m}$ Polybead microspheres (cat. \#07312) and $10.0 \mu \mathrm{m}$ Polybead microspheres (cat. \#17136). Stock suspensions of silica $\left(\mathrm{SiO}_{2}\right)$ beads in sizes of 1.0 (cat. $\left.\# \mathrm{SiO}_{2}-\mathrm{F}-1.0\right)$ and 10.0 $\mu \mathrm{m}$ (cat. \#SiO $2-\mathrm{F}-10.0)$ were purchased from microParticles $\mathrm{GmbH}$ (Berlin, Germany).

All applied PS beads consisted of PS, as confirmed by Raman spectroscopy (Supporting Information S1, Figures S1S6), and were equally dispersed as uniform spherical-shaped material in stock suspensions (exemplarily shown for 3.0, 6.0, and $10.0 \mu \mathrm{m}$ PS beads; Supporting Information S2.1, Figures S7-S9). Bead densities of stock solutions (PS: $0.5-10.0 \mu \mathrm{m}$; $\left.\mathrm{SiO}_{2}: 1.0,10.0 \mu \mathrm{m}\right)$ were verified by counting the beads in defined dilutions of the stock suspensions using a hemocytometer (Neubauer improved; $0.02 \mathrm{~mm}$ chamber depth; 
BRAND GMBH + CO KG, Wertheim, Germany) and deviated by not more than $15 \%$ from the values reported by the manufacturer (Supporting Information S2.2, Table S1). Moreover, beads of $1.0-10.0 \mu \mathrm{m}$ in size were checked regarding their size distributions and corresponded well with the manufacturer specifications (Supporting Information S2.2, Table S1, and Figure S10). All beads had negatively charged surfaces, with measured zeta potentials of $<-40 \mathrm{mV}$ (Supporting Information S2.3, Table S2).

2.4. Toxicity Tests with PS and $\mathrm{SiO}_{2}$ Beads. Bioassays with $C$. elegans were performed according to the standard methods (ISO 10872) with a few modifications. ${ }^{22}$ Nematode toxicity tests were carried out in glass vials to avoid plastic release from the typically used microplates $(10 \mathrm{~mL}$ headspace vials with screw caps; Klaus Ziemer $\mathrm{GmbH}$, Germany) according to an experimental design that included three to five replicates for each treatment (bead sizes and concentrations) and control. Age-synchronization of C. elegans was carried out according to ISO 10872 by filtering mixed populations through a gauze with a $5 \mu \mathrm{m}$ mesh size. Five first-stage (J1) juveniles of $C$. elegans (only living, mobile nematodes) were transferred to replicate vials, each containing $0.25 \mathrm{~mL}$ of microplastic suspension (negative control: M9medium) and $0.25 \mathrm{~mL}$ of bacterial suspension. After $96 \mathrm{~h}$ of exposure in the dark at $20^{\circ} \mathrm{C}$, the nematodes in each replicate were stained (Rose bengal; $300 \mathrm{mg} / \mathrm{mL}$ ) to facilitate counting, and then heat-killed at $80{ }^{\circ} \mathrm{C}$ for $15 \mathrm{~min}$ and stored at $4{ }^{\circ} \mathrm{C}$. To quantify nematode reproduction, the number of offspring of adult hermaphrodites in each replicate was determined under a stereomicroscope at 40-fold magnification (Leica L2) and divided by the number of introduced test organism (reproduction $=$ offspring/test organism). For each treatment, $\%$ inhibition of reproduction (\% IR) was calculated by using the following equation: \% IR $=R_{\mathrm{X}} / R_{\mathrm{C}} \times 100$, where $R_{\mathrm{X}}$ and $R_{\mathrm{C}}$ are the reproduction values for treatment $\mathrm{X}$ and the negative control, respectively. The number of offspring per test sample was plotted against the corresponding chemical concentration from that sample (mg PS/SiO 2 or styrene $/ \mathrm{mL}$ ).

Toxicity thresholds (EC50-values) were determined by exposing C. elegans (N2 strain) to a concentration series of PS beads prepared by diluting the stock suspensions with M9medium in glass vials (cat. \#VT1800110F, A-Z AnalytikZubehör $\mathrm{GmbH}$, Langen, Germany) to achieve concentrations twice as high as the intended test concentrations: $0.1 \mu \mathrm{m}(0.04$, $0.08,0.16,0.32,0.64$, and $1.28 \mathrm{mg} / \mathrm{mL}), 0.5 \mu \mathrm{m}(0.21,0.43$, $0.86,1.72,3.43$, and $6.87 \mathrm{mg} / \mathrm{mL}), 1.0 \mu \mathrm{m}(0.148,0.445$, 1.335 , and $4.005 \mathrm{mg} / \mathrm{mL}), 3.0 \mu \mathrm{m}(0.463,1.389,4.167$, and $12.5 \mathrm{mg} / \mathrm{mL}), 6.0 \mu \mathrm{m}(0.78,3.1,6.3$, and $12.5 \mathrm{mg} / \mathrm{mL})$, and $10.0 \mu \mathrm{m}(0.78,3.1,6.3$, and $12.5 \mathrm{mg} / \mathrm{mL})$.

To test whether toxicity was caused by the physical effects of the beads themselves, the nematodes were also exposed to 1.0 and $10.0 \mu \mathrm{m} \mathrm{SiO}$ beads prepared by diluting stock suspensions with M9-medium in glass vials to achieve concentrations twice as high as the intended test concentrations: $1.0(0.62,1.9,5.6,16.7$, and $50 \mathrm{mg} / \mathrm{mL})$ and $10.0 \mu \mathrm{m}$ $(5.6,16.7$, and $50 \mathrm{mg} / \mathrm{mL})$.

2.5. Oxidative Stress Testing. To determine whether PS toxicity was induced by oxidative stress, in addition to wildtype C. elegans (N2 strain), individuals of the mutant strain sod2 were exposed to PS beads of $0.1 \mu \mathrm{m}(0.15 \mathrm{mg} / \mathrm{L}), 0.5 \mu \mathrm{m}$ $(0.56 \mathrm{mg} / \mathrm{mL}), 1.0 \mu \mathrm{m}(0.55 \mathrm{mg} / \mathrm{mL})$, and $3.0 \mu \mathrm{m}(2.3 \mathrm{mg} /$ $\mathrm{mL}$ ) as described above (Section 2.4). As a positive control, the two strains were also exposed to paraquat dichloride (PQ)
(14 mg/L; PESTANAL analytical standard; Fluka), known to induce oxidative stress in C. elegans. ${ }^{43}$

2.6. Chemical Toxicity by Leachates and Styrene Monomers. 2.6.1. Toxicity of Leachates. The toxicity by substances leaching out from the PS beads was assessed by producing leachates from suspensions of 1.0 and $6.0 \mu \mathrm{m}$ PS beads. Beads of both sizes $\left(1.0 \mu \mathrm{m}: 2.4 \times 10^{9}\right.$ beads $/ \mathrm{mL} ; 6.0$ $\mu \mathrm{m}: 6.8 \times 10^{7}$ beads $/ \mathrm{mL}$; densities correspond to a total surface area of approximately $75 \mathrm{~cm}^{2} / \mathrm{mL}$ ) were incubated for $96 \mathrm{~h}$ in M9-medium and then centrifuged for $15 \mathrm{~min}$ at $4500 \mathrm{~g}$ to remove the remaining beads from the supernatant. For the $1.0 \mu \mathrm{m}$ PS beads, four centrifugation steps were needed until the beads were no longer detected with fluorescence microscopy (400× magnification; Zeiss Axio Scope.A1, Jena, Germany) in the supernatant. The final supernatant was used to resuspend an appropriate amount of bacteria to achieve a bacterial density of $500 \mathrm{FAU}$, which was used in the toxicity test with C. elegans as described for the tests of PS beads.

2.6.2. Toxicity Test of the Styrene Monomer Using Headspace Passive Dosing. The toxicity of styrene was tested using headspace passive dosing for maintaining a stable styrene exposure throughout the test. ${ }^{44}$ Pure liquid styrene served as the passive dosing donor for testing at the solubility limit, and triglyceride oil containing $1,3,10$, and $30 \%(\mathrm{w} / \mathrm{w})$ styrene was used to control lower exposure levels. More specifically, $0.2 \mathrm{~mL}$ of styrene ( $\geq 99.5 \%$; Carl Roth $\mathrm{GmbH}$; Karlsruhe, Germany) and mixtures of styrene with the triglyceride oil Miglyol 812 (Cremer Oleo $\mathrm{GmbH} \&$ Co. KG; Hamburg, Germany) were added to $0.3 \mathrm{~mL}$ glass inserts embedded with glass wool to increase the surface area for passive dosing (Supporting Information S5, Table S3). The inserts were placed into $20 \mathrm{~mL}$ headspace glass vials (test vials) that were filled with $1 \mathrm{~mL}$ of test medium (containing E. coli as food: 500 FAU) containing five first-stage juveniles (J1) of C. elegans. After placing the glass inserts into the test vials, the vials were tightly closed with screw caps. The medium was then pre-equilibrated for $4 \mathrm{~h}$ before incubating the nematodes for $96 \mathrm{~h}$ at $20{ }^{\circ} \mathrm{C}$.

2.6.3. Chemical Activity of the Styrene Monomer in PS Suspensions and Toxicity Tests. Styrene can partition from the PS beads into the aqueous medium and from there to the headspace of the vial. The PS beads in this manner can act as a passive-dosing donor for the styrene monomer, with the equilibrium styrene concentrations in the PS stock suspensions expressing the maximum exposure to the styrene monomer within the dose-response tests described in Section 2.4. Thus, measuring styrene exposures in the suspensions and comparing them with the EC50 value of styrene can help determine whether the leached styrene monomer can exert toxicity to nematodes. The styrene levels in the PS bead suspensions and in the styrene toxicity tests were both measured by headspace analysis, as described by Trac et al. ${ }^{44}$ Headspace samples above PS bead suspensions ( $2 \mathrm{~mL}$ of $0.1,1.0$, and $10.0 \mu \mathrm{m}$ PS beads) and above passive dosing donor solutions were taken using a CTC PAL RSI 85 autosampler (CTC Analytics, Zwingen, Switzerland) and then injected on an Agilent Technologies GC-MSD system (7890B/5877A GC/MSD) for analysis. The GC-MS program and the determination of chemical activity of styrene were followed as described by Trac et al. ${ }^{44}$

2.7. Food Availability. The dependence of toxicity on the food density was evaluated by exposing C. elegans to PS beads of all sizes $(0.1-10.0 \mu \mathrm{m})$ at concentrations corresponding to the respective EC50 values and to different food densities (125 $\mathrm{FAU}=2.5 \times 10^{8} \mathrm{E}$. coli cells $/ \mathrm{mL}, 250 \mathrm{FAU}=5 \times 10^{8} \mathrm{E}$. coli 
cells $/ \mathrm{mL}, 500 \mathrm{FAU}=10^{9} \mathrm{E}$. coli cells $/ \mathrm{mL}, 1000 \mathrm{FAU}=2 \times 10^{9}$ E. coli cells $/ \mathrm{mL}$, and $2000 \mathrm{FAU}=4 \times 10^{9} \mathrm{E}$. coli cells $/ \mathrm{mL}$ ). The toxicity of $\mathrm{SiO}_{2}$ beads as a function of food density was also determined by exposing the nematodes to 1.0 and 10.0 $\mu \mathrm{m} \mathrm{SiO}_{2}$ beads at their EC50 values and to the same food densities as in the PS experiment. Both experiments were conducted as described in Section 2.4.

2.8. Detection of PS Beads in C. elegans. For each PS bead size and concentration, additional replicates were set up to verify the uptake of beads into the intestine of $C$. elegans after $96 \mathrm{~h}$ of exposure under the same condition as in the toxicity tests. Larger $(6.0$ and $10.0 \mu \mathrm{m})$ PS beads could be detected without labeling using light microscopy (400X magnification), whereas smaller $(0.1-3.0 \mu \mathrm{m})$ PS beads were fluorescently labeled for detection by fluorescence microscopy (400× magnification; Zeiss Axio Scope.A1, Jena, Germany). For each treatment, 5-10 nematodes were mounted on a microscopic slide and embedded in glycerol according to the standard procedures. ${ }^{45,46}$

2.9. Data Analysis. Concentration-response curves were fitted to the data using a logistic model $(p<0.05$ indicated significant regression of the sigmoidal logistic model; SigmaPlot 11.0 Systat Software Inc.), from which median effect concentrations \pm standard deviations (EC50 \pm SD) were calculated. For the toxicity test of the styrene monomer, EC50 values were first determined on a chemical activity basis and then converted to freely dissolved concentrations $\left(C_{\text {free }}\right)$ using a solubility of styrene of $300 \mathrm{mg} / \mathrm{L}$ (chemspider.com; $C_{\text {free }}=$ chemical activity $\times$ water solubility).

A one-way ANOVA was used to analyze whether the reproduction (number of offspring per organism) of C. elegans exposed to the leachates of 1.0 and $6.0 \mu \mathrm{m}$ PS beads differed compared to the control. The data were checked for normality (Shapiro-Wilk test) and for homoscedasticity (Levene's test) but were not transformed to improve normality. A significance level of $p<0.05$ was used for all comparisons.

\section{RESULTS AND DISCUSSION}

3.1. Size-Dependent Inhibitory Effects of PS Beads. $C$. elegans ingested PS beads of $0.1,0.5,1.0$, and $3.0 \mu \mathrm{m}$, all of which were found throughout the nematode's intestinal system (from the buccal cavity to the pro- and metacorpus, isthmus, terminal bulb, pre-intestine, intestine, post-intestine, and rectum). No PS beads were detected in nematode tissues (e.g., the gonads) or in the intestinal cells nor were 6.0 and $10.0 \mu \mathrm{m}$ beads seen in the nematode's body after $96 \mathrm{~h}$ of bead exposure (Supporting Information S3, Figure S11). These results can be explained by the size of the buccal cavity of $C$. elegans, which during $96 \mathrm{~h}$ of development (from J1 to the adult stage) increased in size from $1.3 \pm 0.1 \mu \mathrm{m}$ (mean $\pm \mathrm{SD}$; $n=16)$ to $4.38 \pm 0.49 \mu \mathrm{m}(n=17$; Supporting Information S4, Figure S12). Other studies have also reported that $4.5 \mu \mathrm{m}$ particles could not be ingested by $C$. elegans but these ingested PS beads $(\leq 3.0 \mu \mathrm{m})$ were transported from the pharynx through the isthmus and terminal bulb into the intestine. ${ }^{47}$ Boyd and co-workers ${ }^{48}$ similarly showed that C. elegans is able to ingest latex beads with diameters $\leq 3.4 \mu \mathrm{m}$ but not larger beads. Thus, the uptake of particles in $C$. elegans is strictly governed by the maximal size of the buccal cavity, as also demonstrated for other nematode species. ${ }^{15}$ The latter study showed that the buccal cavity must be 1.3 times larger than the PS beads before they can be ingested. ${ }^{15}$ Thus, as the buccal cavity of the developing nematodes increased in size during the
$96 \mathrm{~h}$ of the toxicity test, the internal exposure time (after ingestion in the nematode's intestinal system) depended on the bead diameter. PS beads of 0.1 and $0.5 \mu \mathrm{m}$ in size would already have been ingested by J1 nematodes such that $96 \mathrm{~h}$ of internal exposure can be assumed, whereas the ingestion of 1.0 and $3.0 \mu \mathrm{m}$ beads would have started after approximately 24 and $60 \mathrm{~h}$, respectively, with internal exposure then limited to 72 and $36 \mathrm{~h}$, respectively. For 6.0 and $10.0 \mu \mathrm{m}$ PS beads, internal exposure was unlikely.

If internal exposure is required for toxicity (according to hypothesis 1), then 6.0 and $10.0 \mu \mathrm{m}$ PS beads should have had no effects and $3.0 \mu \mathrm{m}$ beads should have had only marginal effects on C. elegans reproduction. However, beads of all tested sizes $(0.1-10.0 \mu \mathrm{m})$ showed clear, dose-dependent inhibitory effects (Figure 1a), which suggested that, to some extent,

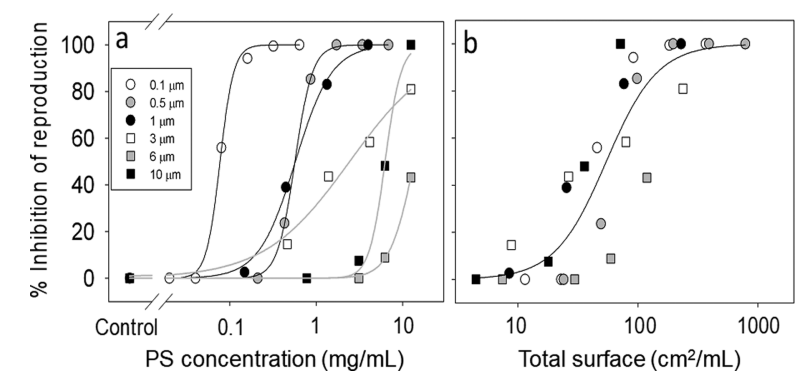

Figure 1. Dose-response curves for PS beads of different sizes. Mean inhibition $(\% ; n=4)$ of reproduction in C. elegans exposed for $96 \mathrm{~h}$ to beads of different sizes (diameter: 0.1, 0.5, 1.0, 3.0, 6.0, and $10.0 \mu \mathrm{m}$ ) as a function of (a) the PS concentration $(\mathrm{mg} / \mathrm{mL})$ and $(b)$ the total surface area of all beads in the system $\left(\mathrm{cm}^{2} / \mathrm{mL}\right)$. Negative values of inhibition were set to " 0 "; curves were fitted using a sigmoidal logistic model (Figure 1a: for $p$ - and $r^{2}$-values, see Table 1; Figure 1b: $p<$ $\left.0.0001, r^{2}=0.794\right)$.

external exposure to the beads also resulted in inhibition. Nevertheless, the toxicity of the PS beads to C. elegans was clearly related to their size (Figure 1a, Table 1), with $0.1 \mu \mathrm{m}$ beads being the most toxic, followed by $0.5,1.0$, and $3.0 \mu \mathrm{m}$ PS beads and 6.0 and $10.0 \mu \mathrm{m}$ PS beads being the least toxic. Sizedependent effects of PS beads have also been reported in other studies of C. elegans ${ }^{17}$ and studies of rotifers ${ }^{27}$ and marine copepods. ${ }^{49}$ Generally, it is assumed that with particles of

Table 1. Effect (EC50 Values) of PS Beads, Silica $\left(\mathrm{SiO}_{2}\right)$ Beads, and Styrene Monomers on the Reproduction of $C$. elegans after $96 \mathrm{~h}$ of Exposure ${ }^{a}$

\begin{tabular}{cllll} 
& \multicolumn{2}{c}{ EC50 $( \pm \mathrm{SD})$} & & \\
\cline { 2 - 3 } $\begin{array}{c}\text { bead diameter } \\
(\mu \mathrm{m})\end{array}$ & \multicolumn{1}{c}{$\mathrm{mg} / \mathrm{mL}$} & $\times 10^{9}$ beads $/ \mathrm{mL}$ & \multicolumn{1}{c}{$P$} & $r^{2}$ \\
PS 0.1 & $0.077 \pm 0.002$ & $140 \pm 2.8$ & $<0.0001$ & 0.998 \\
$\mathrm{PS} 0.5$ & $0.57 \pm 0.006$ & $8.3 \pm 0.087$ & $<0.0001$ & 1.000 \\
$\mathrm{PS} 1.0$ & $0.57 \pm 0.05$ & $1.0 \pm 0.098$ & 0.0024 & 0.998 \\
$\mathrm{PS} 3.0$ & $2.3 \pm 1.4$ & $0.16 \pm 0.098$ & 0.0146 & 0.985 \\
$\mathrm{PS} 6.0$ & $12.9 \pm 9.1$ & $0.11 \pm 0.076$ & 0.0010 & 0.996 \\
$\mathrm{PS} \mathrm{10.0}$ & $6.3 \pm 0.5$ & $0.011 \pm 0.0008$ & 0.0042 & 0.999 \\
$\mathrm{SiO}_{2} 1.0$ & $3.0 \pm 0.13$ & $3.4 \pm 0.15$ & $<0.0001$ & 0.999 \\
$\mathrm{SiO}_{2} 10.0$ & $>25$ & $>0.026$ & & \\
styrene & $0.024 \pm 0.001$ & & 0.0015 & 0.999
\end{tabular}

${ }^{a}$ Median effect concentrations (EC50 \pm SD) for PS beads of different sizes (diameter: 0.1, 0.5, 1.0, 3.0, 6.0, and $10.0 \mu \mathrm{m}$ ) and $\left(\mathrm{SiO}_{2}\right)$ beads (diameter: 1.0 and $10.0 \mu \mathrm{m}$ ) as a function of the bead concentration. 
decreasing size, their uptake and toxicity increase. This has been demonstrated for nanosized particles, which are able to cross biological membranes to cause intracellular damage. ${ }^{50,51}$ However, mechanical damage in the intestine, which would not require cellular uptake, might also explain the toxic effects of small particles. ${ }^{17}$ Our study further indicates that the ingestion of PS beads enhances toxicity, given that smaller beads $(0.1-1.0 \mu \mathrm{m})$, ingested by C. elegans throughout the 96 $\mathrm{h}$ of toxicity testing, caused considerably higher toxicity than did PS beads that were too large $(3.0-10.0 \mu \mathrm{m})$ to enter the nematode's gut or entered for only a short period.

3.2. Total Surface Area Determined Inhibitory Effects of PS Beads. As non-ingested PS beads also induced adverse effects, other mechanisms, not requiring ingestion, have likely been responsible for their toxicity. The size of a particle is inherently coupled to its surface area, a relationship that is also of toxicological relevance. ${ }^{26}$ The ratio of the surface area to the size of the particle increases exponentially with the decreasing particle size. ${ }^{50}$ An increased surface reactivity of small particles might translate into a greater biological activity per unit mass. ${ }^{50}$ Indeed, our results indicated that toxicity was determined by the total surface area per volume $\left(\mathrm{cm}^{2} / \mathrm{mL}\right)$. Figure $1 \mathrm{~b}$ shows that the inhibition of reproduction after exposure of the nematodes to PS beads of various sizes followed a single dose-response curve when the effects were plotted against the total surface area per volume. The EC50 value calculated from this curve (Figure 1b) was $55.4( \pm 12.9)$ $\mathrm{cm}^{2} / \mathrm{mL}$; thus, irrespective of the bead size, a $50 \%$ effect will occur if the sum of the surfaces of all beads in the test system is $55 \mathrm{~cm}^{2} / \mathrm{mL}$. Accordingly, for $0.1 \mu \mathrm{m}$ PS beads, a 10,000 -fold higher density and a 100 -fold lower concentration $\left(1.8 \times 10^{11}\right.$ beads $/ \mathrm{mL}$; $0.1 \mathrm{mg} / \mathrm{mL}$ ) were needed to induce effects comparable to those of $10.0 \mu \mathrm{m}$ beads $\left(1.8 \times 10^{7}\right.$ beads/ $\mathrm{mL} ; 10 \mathrm{mg} / \mathrm{mL}$ ), which agrees well with the EC50 values for the bead density and PS concentration determined in our study (Table 1).

3.3. Chemical Toxicity by Styrene and Leachates. The leaching of chemicals from the beads and into the aqueous medium is related to their surface area and may be an additional cause of toxicity. ${ }^{29}$ The chemical most likely released from commercial PS particles is the monomer styrene, as shown for other PS-based products. ${ }^{52}$ Toxic effects of styrene have been demonstrated in aquatic invertebrates, with an EC50 value $(48 \mathrm{~h})$ of $4.7 \mathrm{mg} / \mathrm{L}$ for Daphnia magna and an LC50 (the concentration inducing 50\% lethality) value (96 h) of $9.5 \mathrm{mg} / \mathrm{L}$ for Hyalella azteca. ${ }^{33}$ Styrene damaged DNA in the hemolymph of the blue mussel Mytilus edulis L., ${ }^{54}$ and very low concentrations $(0.04-1.7 \mu \mathrm{g} / \mathrm{L})$ of styrene dimers and trimers were shown to alter the fertility of daphnids. ${ }^{55}$

However, we could demonstrate that only low amounts of styrene partitioned from the PS bead stock suspensions $(25 \mathrm{mg}$ $\mathrm{PS} / \mathrm{mL}$ ) into the water. Headspace GC-MS revealed chemical activities of $0.0015( \pm 0.0001), 0.0030( \pm 0001)$, and 0.0021 $( \pm 0.0002)$ in suspensions of $0.1,1.0$, and $10.0 \mu \mathrm{m}$ PS beads, respectively (Supporting Information S5, Table S4). These correspond to freely dissolved concentrations $\left(C_{\text {free }}\right)$ between 0.45 and $0.90 \mathrm{mg} / \mathrm{L}$ at a water solubility of $300 \mathrm{mg} / \mathrm{L}$, meaning that $0.002-0.004 \%$ of the PS leached into the water as the monomer styrene (Supporting Information S5, Table S4). The concentration of the leached styrene showed no relation to the total surface area of the PS beads present in the suspension, which spanned a range of $143-14,300 \mathrm{~cm}^{2}$ for $25 \mathrm{mg} / \mathrm{mL}$, regarding $10.0-0.1 \mu \mathrm{m}$ beads, but had comparable $C_{\text {free }}$ of styrene. Chemical activities and freely dissolved concentrations of styrene in dilutions of the PS bead suspensions will be lower than those in the concentrated bead suspension, while being higher than calculated via dilution factors due to the repartitioning of styrene from the PS beads. ${ }^{56}$

In the styrene toxicity test, a $50 \%$ inhibition of C. elegans' reproduction was obtained at a chemical activity of 0.080 (Supporting Information S5, Figure S14) corresponding to 24 mg styrene/L (Table 1), which exceeds freely dissolved concentrations of styrene in the concentrated PS suspensions by $1-2$ orders of magnitude. We can thus exclude that the leached styrene caused the observed toxicity in the diluted PS suspensions.

To exclude potential toxic effects of leached chemicals other than styrene monomers, the leachates produced from suspensions of 1.0 and $6.0 \mu \mathrm{m}$ PS beads ( 1.3 and $8.1 \mathrm{mg} /$ $\mathrm{mL}$, respectively; corresponding to $75 \mathrm{~cm}^{2} / \mathrm{mL}$ ) were tested for their toxicity. C. elegans reproduction was not negatively affected by the leachates of the 1.0 and $6.0 \mu \mathrm{m}$ beads (one-way ANOVA; $p=0.093)$, which instead slightly stimulated reproduction (163.6 \pm 19.24 and $184.18 \pm 10.06$ offspring per test organism, respectively) compared to the control $(156.14 \pm 11.67)$. By contrast, Zhao and co-workers ${ }^{16}$ showed a significant decrease in the brood size and locomotion behavior of $C$. elegans and the induction of intestinal ROS production in this nematode in response to the leachates of 0.1 $\mu \mathrm{m}$ PS particles at concentrations of $0.010 \mathrm{mg} / \mathrm{mL}$. However, that study used carboxyl-coated PS beads and a longer leaching period (1 week), which might explain the discrepancy between its results and our own.

3.4. Oxidative Stress. Because ROS production can be triggered by small particles, their chemical composition, and their large reactive surface area, ${ }^{26}$ we were wondering whether the PS beads would induce oxidative stress, which then could be at least partly responsible for the observed toxicity. Indeed, the induction of ROS generation and/or oxidative stress by nanoplastics and microplastics have been observed in rotifers, ${ }^{27}$ copepods, $^{57}$ fish, ${ }^{17,58}$ and in other studies of C. elegans. ${ }^{16,17}$ However, we found that PS beads $(0.1-3.0 \mu \mathrm{m})$ did not induce oxidative stress in $C$. elegans. Although the $C$. elegans mutant strain, which is hypersensitive to oxidative stress (sod2), was considerably more sensitive to PQ compared to the wild-type strain N2 (Table 2), no difference in sensitivity of these two strains could be observed for the PS beads. However, mild oxidative stress induced by the PS beads might have been compensated by the upregulation of other sod genes. ${ }^{40,59}$ Accordingly, we cannot completely rule out that a weak

Table 2. Comparison of Effects Induced by Oxidative Stress in Two Strains of C. elegans ${ }^{a}$

\begin{tabular}{lccc} 
& & \multicolumn{2}{c}{$\begin{array}{c}\text { inhibition of reproduction } \\
(\% \text {; mean } \pm \mathrm{SD})\end{array}$} \\
\cline { 3 - 4 } $\begin{array}{c}\text { PS bead } \\
\text { diameter }\end{array}$ & $\begin{array}{c}\text { concentration } \\
(\mathrm{mg} / \mathrm{mL})\end{array}$ & $\mathrm{N} 2$ & sod-2 \\
$0.1 \mu \mathrm{m}$ & 0.15 & $56.0 \pm 34.3$ & $66.0 \pm 17.5$ \\
$0.5 \mu \mathrm{m}$ & 0.56 & $27.6 \pm 15.5$ & $19.0 \pm 17.3$ \\
$1.0 \mu \mathrm{m}$ & 0.55 & $24.2 \pm 36.0$ & $34.1 \pm 11.0$ \\
$3.0 \mu \mathrm{m}$ & 2.3 & $64.5 \pm 13.3$ & $62.2 \pm 2.9$ \\
$\mathrm{PQ}$ & 0.014 & $-34.1 \pm 6.1$ & $60.3 \pm 4.1$
\end{tabular}

${ }^{a}$ Inhibition of reproduction (\%; mean $\pm \mathrm{SD}$ ) in C. elegans (N2; sod-2) exposed for $96 \mathrm{~h}$ to PS beads of different diameters $(0.1-3.0 \mu \mathrm{m})$ in aqueous suspension and to $\mathrm{PQ}$ an inducer of oxidative stress. 


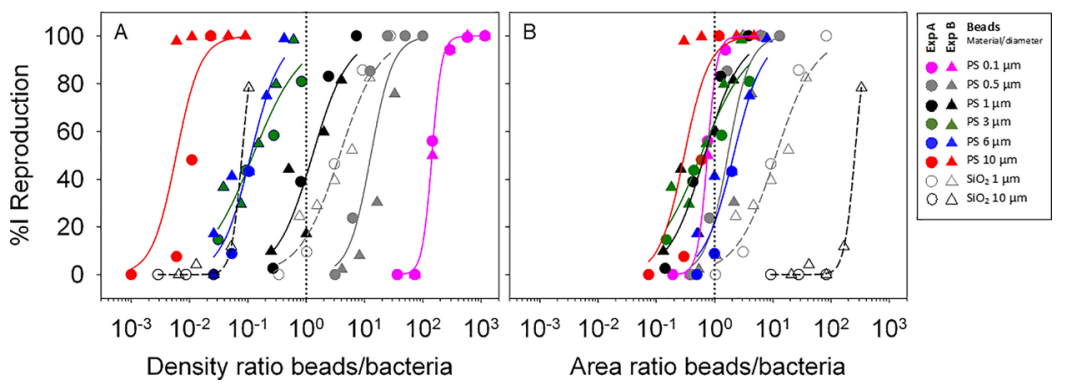

Figure 2. Dose-response curves based on the ratio of PS or silica $\left(\mathrm{SiO}_{2}\right)$ beads to bacteria. Inhibition (\%) of reproduction in C. elegans exposed for $96 \mathrm{~h}$ to PS and $\mathrm{SiO}_{2}$ beads of different sizes at various food densities plotted against the ratio of beads/bacteria, in terms of $(\mathrm{A})$ total numbers and (B) the total surface area of beads or bacterial cells, circles = experiment A: constant bacterial density at varying bead densities; triangles = experiment B: constant density of beads at varying bacterial densities. The curves were fitted using a sigmoidal logistic model; for all curves: $r^{2} \geq$ $0.8, p<0.01$ (exception: PS $10.0 \mu \mathrm{m}, r^{2}=0.62, p=0.056$ ).

oxidative stress contributed to the observed effects of the PS beads to induce oxidative stress.

3.5. Food Availability. Mechanical damage of the nematode gut, as proposed by Lei and co-workers, ${ }^{17}$ does not fully explain the observed effects because beads that could not be ingested by $C$. elegans also inhibited reproduction (Figure 1, Table 1). However, the beads might have indirectly affected the nematodes by reducing food availability both inside and outside the nematode intestine, as already suggested for copepods. ${ }^{60}$ Our experiments with a varying food supply (bacterial densities) at constant bead densities showed that the inhibitory effects of the beads increased with decreasing bacterial densities (Supporting Information S6, Figure S15). The inhibitory effects of PS and $\mathrm{SiO}_{2}$ beads could be nicely fitted to the ratio of beads to bacteria, regardless if the bacterial or the bead density had been manipulated (Figure 2A) and thus be attributed in part to a reduction in food availability. One mechanism could be that the PS beads bind bacteria and thus limit the food availability to C. elegans. This might explain the effect of the larger, non-ingested beads $(6.0$ and $10.0 \mu \mathrm{m})$. It could be shown that positively charged nanoparticles $\left(\mathrm{NH}_{2}-\right.$ coated $\mathrm{PS}$ and $\mathrm{SiO}_{2}$ particles) heteroagglomerate with bacterial cells, resulting in decreased food availability by C. elegans as a false positive toxic effect. ${ }^{18}$ However, the uncoated PS and $\mathrm{SiO}_{2}$ beads used in the present study were negatively charged (negative zeta potential; Supporting Information S2.3, Table S2) and consequently showed no notable agglomeration with the E. coli cells present in the test system (Supporting Information S7, Figures S16 and S17), which agrees with observations of Hanna and co-workers ${ }^{18}$ that negatively charged particles are not agglomerating with $E$. coli. Thus, it is more plausible that the PS beads diluted the bacteria and, as non-nutritional surrogates, reduced the biomass of nutritional particles randomly ingested by $C$. elegans. This was evidenced by the $50 \%$ inhibition that occurred at a 1:1 dilution of bacteria and the $1.0 \mu \mathrm{m}$ beads (ratio beads/bacteria $=1.2$ ), which are roughly the same size as E. coli (Figure 2A).

However, the bacterial dilution at which $50 \%$ effects occurred was strongly dependent on the bead size and spanned a range of $>4$ orders of magnitude, from 0.006 to 143 beads/bacteria (Figure 2A). If the dilution of bacteria by PS beads was based on the total surface area of bacteria and beads, the single response curves virtually merged to one common response curve (Figure 2B), suggesting that, independent of size, a $50 \%$ effect on reproduction is induced if the surface area of PS beads is as large as that of the food bacteria (mean surface-based EC50 $0_{\text {bacterial dilution: }} 1.0 \pm 0.7$ $(0.3-2.1 \mathrm{bead} /$ bacterial area $))$.

3.6. Plastic-Specific Effect. To determine whether the observed particle-related effects were caused by plastic-specific properties, non-plastic $\mathrm{SiO}_{2}$ beads (1.0 and $10.0 \mu$ m diameter) were also tested for their effects on $C$. elegans reproduction. The $\mathrm{SiO}_{2}$ beads were considerably less toxic than PS beads of the same size class (Table 1; Supporting Information S8, Figure S18). For $1.0 \mu \mathrm{m}$ beads, their EC50 value was $>3$ times higher if toxicity is based on bead density $\left(3.4 \times 10^{9}\right.$ vs $1.02 \times$ $10^{9}$ beads $/ \mathrm{mL}$; Table 1$),>5$ times higher if toxicity is based on bead mass fractions ( $3.0 \mathrm{vs} 0.57 \mathrm{mg} / \mathrm{mL}$; Table 1 ), and 2 times higher if toxicity is based on the total surface (107 vs $55 \mathrm{~cm}^{2}$ / $\mathrm{mL})$. For $10.0 \mu \mathrm{m} \mathrm{SiO}$ beads, no effects occurred except at the highest tested concentrations $\left(25 \mathrm{mg} \mathrm{SiO} / \mathrm{mL} ; 2.6 \times 10^{7}\right.$ beads $/ \mathrm{mL} ; 82 \mathrm{~cm}^{2} / \mathrm{mL}$ ); thus, even for the larger beads, the toxicity of the PS beads was considerably higher than that of the $\mathrm{SiO}_{2}$ beads (Table 1). Moreover, also the interaction of the beads seems to be dependent on their material, as $\mathrm{SiO}_{2}$ beads induced toxic effects on C. elegans at considerably higher bead/ bacteria ratios than PS beads, if based on the total surface area (Figure 2B). Although PS beads, independent on size, caused $50 \%$ inhibition of reproduction at a surface area ratio of 1 (beads/bacteria), for $\mathrm{SiO}_{2}$ beads, surface area ratios of 10 or even 250 (beads/bacteria) were necessary to cause $50 \%$ effects for 1.0 and $10.0 \mu \mathrm{m}$ beads, respectively (Figure $2 \mathrm{~B}$ ).

The lower inhibitory effects of the $\mathrm{SiO}_{2}$ compared to PS beads may have been due to the higher specific density of $\mathrm{SiO}_{2}$ $(1.85 \mathrm{~g} / \mathrm{mL}$; manufacturer specifications) than of PS ( $1.05 \mathrm{~g} /$ $\mathrm{mL}$; manufacturer specifications). Particles with a specific density close to that of water may be more easily ingested by nematodes than denser and thus less buoyant particles. The specific density of E. coli $\left(1.07-1.11 \mathrm{~g} / \mathrm{mL} ;^{61}\right)$ is similar to that of PS beads $(1.05 \mathrm{~g} / \mathrm{mL})$ such that for C. elegans, the latter may be taken up more readily than denser $\mathrm{SiO}_{2}$ beads and therefore have a greater impact on the dietary ingestion of bacteria (Section 3.5). Thus, the material-specific properties of nanoand microparticles, such as their specific density, may influence not only the fate and transport of the particles ${ }^{62}$ but also their ecotoxicological behavior. Pluskota and co-workers ${ }^{63}$ compared the translocation of nanosized PS and $\mathrm{SiO}_{2}$ beads (50 $\mathrm{nm}$ diameter) in the organs of $C$. elegans and found that while PS beads were able to enter $C$. elegans tissues (intestine and proximal gonad), $\mathrm{SiO}_{2}$ beads were only able to enter the nematode's gut. The difference may have been due to differences in the densities of the beads. The authors ${ }^{63}$ also found significant inhibitory effects on progeny production 
(approximately 20\% inhibition) of $0.05 \mu \mathrm{m} \mathrm{SiO}$ beads at 2.5 $\mathrm{mg} / \mathrm{mL}$. Thus, the $0.05 \mu \mathrm{m} \mathrm{SiO}$, beads in that study were only slightly less toxic than the $1.0 \mu \mathrm{m} \mathrm{SiO}_{2}$ beads in the present study ( $50 \%$ inhibition at $3 \mathrm{mg} / \mathrm{mL}$; Table 1 ) but far less toxic than our $0.1 \mu \mathrm{m}$ PS beads ( $50 \%$ inhibition at $0.08 \mathrm{mg} / \mathrm{mL}$ ), supporting the outcome of the present study.

3.7. Environmental Implications. Four major conclusions can be drawn from the results of this study: (1) the total surface area of microbeads determined their toxicity; (2) the styrene monomer did not cause the observed toxicity of PS beads; (3) the effects of microbeads were largely determined by their material composition, with the specific density of the material being a crucial characteristic; and (4) microbeads indirectly affected nematodes by altering food availability. Our results highlight that investigations of the ecological risk of microplastic particles must also consider indirect food web effects and the nutritional conditions within a specific habitat. However, in extrapolating our findings to the ecological risk of microplastics in the environment, the following must be kept in mind: (1) only spherical beads were tested, although microplastics with other shapes occur in aquatic systems and their effects may differ. ${ }^{64}$ (2) Only commercially available pristine beads were tested, whereas in natural systems, biological processes and weathering will change the behavior of particles. ${ }^{5,65}$ (3) The effects observed in the present study occurred at relatively high PS bead concentrations (EC50 values of $0.08-13 \mathrm{mg} / \mathrm{mL}$ ). However, because of analytical limitations, for the size range of the tested beads, no reliable data on microplastic concentrations in field samples are available. $^{66}$

Our data provide reliable toxicity thresholds that can be used in more thorough risk assessments, as soon as field data become available. In studies modeling concentrations on the basis of mass-conserving fragmentation processes, ${ }^{67}$ our results showed that the first effects on $C$. elegans occur at concentrations approximately 50- to 4000-fold higher than the highest expected microplastic concentration in the field, which implies a low risk of microplastics for nematodes. Nonetheless, in the mass-conserving fragmentation of microplastics, the total surface area will probably increase such that the risk for nematodes increases with progressive fragmentation. Moreover, the biofouling of plastic particles might enhance their sedimentation, leading to higher exposure concentrations in sediments and therefore increased risks for benthic organisms, including nematodes. ${ }^{65}$

\section{ASSOCIATED CONTENT}

\section{SI Supporting Information}

The Supporting Information is available free of charge at https://pubs.acs.org/doi/10.1021/acs.est.9b06583.

Additional information on the experimental setups; growth curves for the buccal cavity of C. elegans; bead characteristics; figures showing no agglomeration of beads and bacteria; photo montage showing the ingestion of PS beads; and results describing the chemical activity, the toxic effects dependent on the food availability of PS, and silica beads on C. elegans reproduction (PDF)

\section{AUTHOR INFORMATION}

Corresponding Author

Marie-Theres Mueller - Bielefeld University, Bielefeld,

Germany; 이이이.org/0000-0002-9856-9064;

Email: ma.mueller@uni-bielefeld.de

\section{Other Authors}

Hendrik Fueser - Bielefeld University, Bielefeld, Germany

Lam Ngoc Trac - Technical University of Denmark, Kgs. Lyngby, Denmark

Philipp Mayer - Technical University of Denmark, Kgs. Lyngby, Denmark; 이이이.org/0000-0001-5138-7506

Walter Traunspurger - Bielefeld University, Bielefeld, Germany

Sebastian Höss - Bielefeld University, Bielefeld, Germany, and Ecossa, Starnberg, Germany

Complete contact information is available at:

https://pubs.acs.org/10.1021/acs.est.9b06583

\section{Author Contributions}

M.-T.M., H.F., S.H., and W.T. designed the nematode toxicity experiments testing different bead sizes on C. elegans' reproduction. M.-T.M. and S.H. carried out the toxicity tests. H.F. evaluated the Raman spectra data. L.N.T. and P.M. contributed the passive dosing and chemical activity measurements of the styrene monomer. M.-T.M. and H.F. wrote the manuscript. W.T. and S.H. supervised the work. All authors contributed to and approved the final version of the manuscript.

\section{Notes}

The authors declare no competing financial interest.

\section{ACKNOWLEDGMENTS}

We are grateful to Stefanie Gehner for technical assistance, to Cihang Kong of the Biomolecular Photonics Group (Faculty of Physics, Bielefeld University) for recording Raman spectra of the used PS beads, and to Birgit Würz of the Department Environmental Microbiology (Helmholtz-Centre for Environmental Research, Leipzig) for zeta-potential measurements. This research was supported by the German Federal Ministry of Education and Research (BMBF) as part of the project MikroPlaTaS-Microplastics in Dams and Reservoirs: Sedimentation, Spread, Effects (BMBF grant nos. 02WPL1448D and $02 \mathrm{WPL} 1448 \mathrm{E}$ ). All C. elegans strains were provided by the Caenorhabditis Genetic Center and by the Gene Knockout Project at the Oklahoma Medical Research Foundation as a part of the International C. elegans Gene Knockout Consortium.

\section{REFERENCES}

(1) PlasticsEurope. Plastics-The Facts 2017. An Analysis of European Plastics Production, Demand and Waste Data: Brussels, Belgium, 2018.

(2) Wagner, M.; Scherer, C.; Alvarez-Muñoz, D.; Brennholt, N.; Bourrain, X.; Buchinger, S.; Fries, E.; Grosbois, C.; Klasmeier, J.; Marti, T.; Rodriguez-Mozaz, S.; Urbatzka, R.; Vethaak, A.; WintherNielsen, M.; Reifferscheid, G. Microplastics in freshwater ecosystems: what we know and what we need to know. Environ. Sci. Eur. 2014, 26, 12.

(3) Eerkes-Medrano, D.; Thompson, R. C.; Aldridge, D. C. Microplastics in freshwater systems: a review of the emerging threats, identification of knowledge gaps and prioritisation of research needs. Water Res. 2015, 75, 63-82. 
(4) Browne, M. A.; Galloway, T.; Thompson, R. Microplastic-an emerging contaminant of potential concern? Integr. Environ. Assess. Manage. 2007, 3, 559-561.

(5) Galloway, T. S.; Cole, M.; Lewis, C. Interactions of microplastic debris throughout the marine ecosystem. Nat. Ecol. Evol. 2017, 1, 116. (6) Cole, M.; Lindeque, P.; Halsband, C.; Galloway, T. S. Microplastics as contaminants in the marine environment: a review. Mar. Pollut. Bull. 2011, 62, 2588-2597.

(7) Kaiser, D.; Kowalski, N.; Waniek, J. J. Effects of biofouling on the sinking behavior of microplastics. Environ. Res. Lett. 2017, 12, 124003.

(8) Hägerbäumer, A.; Höss, S.; Heininger, P.; Traunspurger, W. Experimental Studies with Nematodes in Ecotoxicology: An Overview. J. Nematol. 2015, 47, 11-27.

(9) Majdi, N.; Threis, I.; Traunspurger, W. It's the little things that count: Meiofaunal density and production in the sediment of two headwater streams. Limnol. Oceanogr. 2017, 62, 151-163.

(10) Traunspurger, W. The biology and ecology of lotic nematodes. Freshwater Biol. 2000, 44, 29-45.

(11) Traunspurger, W.; Höss, S.; Witthöft-Mühlmann, A.; Wessels, M.; Güde, H. Meiobenthic community patterns of oligotrophic and deep Lake Constance in relation to water depth and nutrients. Fundam. Appl. Limnol. 2012, 180, 233-248.

(12) Traunspurger, W.; Bergtold, M.; Goedkoop, W. The effects of nematodes on bacterial activity and abundance in a freshwater sediment. Oecologia 1997, 112, 118-122.

(13) Majdi, N.; Traunspurger, W. Free-Living Nematodes in the Freshwater Food Web: A Review. J. Nematol. 2015, 47, 28-44.

(14) Weber, S.; Traunspurger, W. The effects of predation by juvenile fish on the meiobenthic community structure in a natural pond. Freshwater Biol. 2015, 60, 2392-2409.

(15) Fueser, H.; Mueller, M.-T.; Weiss, L.; Höss, S.; Traunspurger, $\mathrm{W}$. Ingestion of microplastics by nematodes depends on feeding strategy and buccal cavity size. Environ. Pollut. 2019, 255, 113227.

(16) Zhao, L.; Qu, M.; Wong, G.; Wang, D. Transgenerational toxicity of nanopolystyrene particles in the range of $\mu \mathrm{g} \mathrm{L}^{-1}$ in the nematode Caenorhabditis elegans. Environ. Sci.: Nano 2017, 4, 23562366

(17) Lei, L.; Wu, S.; Lu, S.; Liu, M.; Song, Y.; Fu, Z.; Shi, H.; RaleySusman, K. M.; He, D. Microplastic particles cause intestinal damage and other adverse effects in zebrafish Danio rerio and nematode Caenorhabditis elegans. Sci. Total Environ. 2018, 619-620, 1-8.

(18) Hanna, S. K.; Montoro Bustos, A. R.; Peterson, A. W.; Reipa, V.; Scanlan, L. D.; Hosbas Coskun, S.; Cho, T. J.; Johnson, M. E.; Hackley, V. A.; Nelson, B. C.; Winchester, M. R.; Elliott, J. T.; Petersen, E. J. Agglomeration of Escherichia coli with Positively Charged Nanoparticles Can Lead to Artifacts in a Standard Caenorhabditis elegans Toxicity Assay. Environ. Sci. Technol. 2018, 52, 5968-5978.

(19) Kaletta, T.; Hengartner, M. O. Finding function in novel targets: C. elegans as a model organism. Nat. Rev. Drug Discovery 2006, 5, 387-399.

(20) Félix, M.-A.; Braendle, C. The natural history of Caenorhabditis elegans. Curr. Biol. 2010, 20, R965-R969.

(21) Zullini, A. The ecology of the Lambro river. Riv. Idrobiol. 1988, $27,38-58$.

(22) ISO. Water Quality-Determination of the Toxic Effect of Sediment and Soil Samples on Growth, Fertility and Reproduction of Caenorhabditis elegans (Nematoda). ISO/DIS 10872; International Organization for Standardization: Geneva, Switzerland, 2010.

(23) Traunspurger, W.; Haitzer, M.; Höss, S.; Beier, S.; Ahlf, W.; Steinberg, C. Ecotoxicological assessment of aquatic sediments with Caenorhabditis elegans (Nematoda) - A method for testing in liquid medium and whole sediment samples. Environ. Toxicol. Chem. 1997, $16,245-250$.

(24) Leung, M. C. K.; Williams, P. L.; Benedetto, A.; Au, C.; Helmcke, K. J.; Aschner, M.; Meyer, J. N. Caenorhabditis elegans: an emerging model in biomedical and environmental toxicology. Toxicol. Sci. 2008, 106, 5-28.
(25) Höss, S.; Williams, P. L. Ecotoxicity testing with nematodes. In Nematodes as Environmental Indicators; Wilson, M. J., Kakouli-Duarte, T., Eds.; CABI: Wallingford, U.K., Cambridge, MA, 2009 pp 208224.

(26) Nel, A.; Xia, T.; Mädler, L.; Li, N. Toxic potential of materials at the nanolevel. Science 2006, 311, 622-627.

(27) Jeong, C.-B.; Won, E.-J.; Kang, H.-M.; Lee, M.-C.; Hwang, D.S.; Hwang, U.-K.; Zhou, B.; Souissi, S.; Lee, S.-J.; Lee, J.-S. Microplastic Size-Dependent Toxicity, Oxidative Stress Induction, and p-JNK and p-p38 Activation in the Monogonont Rotifer (Brachionus koreanus). Environ. Sci. Technol. 2016, 50, 8849-8857.

(28) Bejgarn, S.; MacLeod, M.; Bogdal, C.; Breitholtz, M. Toxicity of leachate from weathering plastics: An exploratory screening study with Nitocra spinipes. Chemosphere 2015, 132, 114-119.

(29) Li, W. C.; Tse, H. F.; Fok, L. Plastic waste in the marine environment: A review of sources, occurrence and effects. Sci. Total Environ. 2016, 566-567, 333-349.

(30) Martínez-Gómez, C.; León, V. M.; Calles, S.; Gomáriz-Olcina, M.; Vethaak, A. D. The adverse effects of virgin microplastics on the fertilization and larval development of sea urchins. Mar. Environ. Res. 2017, 130, 69-76.

(31) Thaysen, C.; Stevack, K.; Ruffolo, R.; Poirier, D.; Frond, H. de; DeVera, J.; Sheng, G.; Rochman, C. M. Leachate From Expanded Polystyrene Cups Is Toxic to Aquatic Invertebrates (Ceriodaphnia dubia). Front. Mar. Sci. 2018, 5, 71.

(32) Holmes, L. A.; Turner, A.; Thompson, R. C. Adsorption of trace metals to plastic resin pellets in the marine environment. Environ. Pollut. 2012, 160, 42-48.

(33) Rochman, C. M.; Manzano, C.; Hentschel, B. T.; Simonich, S. L. M.; Hoh, E. Polystyrene Plastic: A Source and Sink for Polycyclic Aromatic Hydrocarbons in the Marine Environment. Environ. Sci. Technol. 2013, 47, 13976-13984.

(34) Wang, W.; Wang, J. Different partition of polycyclic aromatic hydrocarbon on environmental particulates in freshwater: Microplastics in comparison to natural sediment. Ecotoxicol. Environ. Saf. 2018, 147, 648-655.

(35) Teuten, E. L.; Saquing, J. M.; Knappe, D. R. U.; Barlaz, M. A.; Jonsson, S.; Björn, A.; Rowland, S. J.; Thompson, R. C.; Galloway, T. S.; Yamashita, R.; Ochi, D.; Watanuki, Y.; Moore, C.; Viet, P. H.; Tana, T. S.; Prudente, M.; Boonyatumanond, R.; Zakaria, M. P.; Akkhavong, K.; Ogata, Y.; Hirai, H.; Iwasa, S.; Mizukawa, K.; Hagino, Y.; Imamura, A.; Saha, M.; Takada, H. Transport and release of chemicals from plastics to the environment and to wildlife. Philos. Trans. R. Soc. London, Ser. B 2009, 364, 2027-2045.

(36) Lithner, D.; Larsson, Å.; Dave, G. Environmental and health hazard ranking and assessment of plastic polymers based on chemical composition. Sci. Total Environ. 2011, 409, 3309-3324.

(37) Lithner, D.; Damberg, J.; Dave, G.; Larsson, Å. Leachates from plastic consumer products-screening for toxicity with Daphnia magna. Chemosphere 2009, 74, 1195-1200.

(38) Kwon, B. G.; Koizumi, K.; Chung, S.-Y.; Kodera, Y.; Kim, J.-O.; Saido, K. Global styrene oligomers monitoring as new chemical contamination from polystyrene plastic marine pollution. J. Hazard. Mater. 2015, 300, 359-367.

(39) Stiernagle, T. Maintenance of C. elegans. 2006. WormBook, ed. The C. elegans Research Community, WormBook, doi/10.1895/ wormbook.1.101.1, http://www.wormbook.org.

(40) van Raamsdonk, J. M.; Hekimi, S. Deletion of the mitochondrial superoxide dismutase sod-2 extends lifespan in Caenorhabditis elegans. PLoS Genet. 2009, 5, No. e1000361.

(41) Brenner, S. The Genetics of Caenorhabditis elegans. Genetics 1974, 77, 71-94.

(42) Muschiol, D.; Traunspurger, W. Life cycle and calculation of the intrinsic rate of natural increase of two bacterivorous nematodes, Panagrolaimus sp. and Poikilolaimus sp. from chemoautotrophic Movile Cave, Romania. Nematology 2007, 9, 271-284.

(43) Vanfleteren, J. R. Oxidative stress and ageing in Caenorhabditis elegans. Biochem. J. 1993, 292, 605-608. 
(44) Trac, L. N.; Schmidt, S. N.; Holmstrup, M.; Mayer, P. Headspace Passive Dosing of Volatile Hydrophobic Organic Chemicals from a Lipid Donor-Linking Their Toxicity to WellDefined Exposure for an Improved Risk Assessment. Environ. Sci. Technol. 2019, 53, 13468-13476.

(45) Seinhorst, J. W. A Rapid Method for the Transfer of Nematodes From Fixative To Anhydrous Glycerin. Nematologica 1959, 4, 67-69.

(46) Seinhorst, J. W. On the Killing, Fixation and Transferring To Glycerin of Nematodes. Nematologica 1962, 8, 29-32.

(47) Fang-Yen, C.; Avery, L.; Samuel, A. D. T. Two size-selective mechanisms specifically trap bacteria-sized food particles in Caenorhabditis elegans. Proc. Natl. Acad. Sci. U.S.A. 2009, 106, 20093-20096.

(48) Boyd, W. A.; Cole, R. D.; Anderson, G. L.; Williams, P. L. The effects of metals and food availability on the behavior of Caenorhabditis elegans. Environ. Toxicol. Chem. 2003, 22, 30493055.

(49) Lee, K.-W.; Shim, W. J.; Kwon, O. Y.; Kang, J.-H. SizeDependent Effects of Micro Polystyrene Particles in the Marine Copepod Tigriopus japonicus. Environ. Sci. Technol. 2013, 47, $11278-11283$

(50) Oberdörster, G.; Oberdörster, E.; Oberdörster, J. Nanotoxicology: An emerging discipline evolving from studies of ultrafine particles. Environ. Health Perspect. 2005, 113, 823-839.

(51) Höss, S.; Fritzsche, A.; Meyer, C.; Bosch, J.; Meckenstock, R. U.; Totsche, K. U. Size- and composition-dependent toxicity of synthetic and soil-derived $\mathrm{Fe}$ oxide colloids for the nematode Caenorhabditis elegans. Environ. Sci. Technol. 2015, 49, 544-552.

(52) Withey, J. R. Quantitative analysis of styrene monomer in polystyrene and foods including some preliminary studies of the uptake and pharmacodynamics of the monomer in rats. Environ. Health Perspect. 1976, 17, 125-133.

(53) Cushman, J. R.; Rausina, G. A.; Cruzan, G.; Gilbert, J.; Williams, E.; Harrass, M. C.; Sousa, J. V.; Putt, A. E.; Garvey, N. A.; St. Laurent, J. P.; Hoberg, J. R.; Machado, M. W. Ecotoxicity hazard assessment of styrene. Ecotoxicol. Environ. Saf. 1997, 37, 173-180.

(54) Mamaca, E.; Bechmann, R. K.; Torgrimsen, S.; Aas, E.; Bjørnstad, A.; Baussant, T.; Floch, S. L. The neutral red lysosomal retention assay and Comet assay on haemolymph cells from mussels (Mytilus edulis) and fish (Symphodus melops) exposed to styrene. Aquat. Toxicol. 2005, 75, 191-201.

(55) Tatarazako, N.; Takao, Y.; Kishi, K.; Onikura, N.; Arizono, K.; Iguchi, T. Styrene dimers and trimers affect reproduction of daphnid (Ceriodaphnia dubia). Chemosphere 2002, 48, 597-601.

(56) ter Laak, T. L.; Mayer, P.; Klamer, H. J. C.; Hermens, J. L. M. Effects of dilution on the exposure in sediment toxicity tests- buffering of freely dissolved concentrations and changes in mixture composition. Environ. Toxicol. Chem. 2007, 26, 2187-2191.

(57) Jeong, C.-B.; Kang, H.-M.; Lee, M.-C.; Kim, D.-H.; Han, J.; Hwang, D.-S.; Souissi, S.; Lee, S.-J.; Shin, K.-H.; Park, H. G.; Lee, J.-S. Adverse effects of microplastics and oxidative stress-induced MAPK/ Nrf2 pathway-mediated defense mechanisms in the marine copepod Paracyclopina nana. Sci. Rep. 2017, 7, 41323.

(58) Lu, Y.; Zhang, Y.; Deng, Y.; Jiang, W.; Zhao, Y.; Geng, J.; Ding, L.; Ren, H. Uptake and Accumulation of Polystyrene Microplastics in Zebrafish (Danio rerio) and Toxic Effects in Liver. Environ. Sci. Technol. 2016, 50, 4054-4060.

(59) Qu, M.; Xu, K.; Li, Y.; Wong, G.; Wang, D. Using acs-22 mutant Caenorhabditis elegans to detect the toxicity of nanopolystyrene particles. Sci. Total Environ. 2018, 643, 119-126.

(60) Cole, M.; Lindeque, P.; Fileman, E.; Halsband, C.; Galloway, T. $\mathrm{S}$. The impact of polystyrene microplastics on feeding, function and fecundity in the marine copepod Calanus helgolandicus. Environ. Sci. Technol. 2015, 49, 1130-1137.

(61) Baldwin, W. W.; Myer, R.; Kung, T.; Anderson, E.; Koch, A. L. Growth and buoyant density of Escherichia coli at very low osmolarities. J. Bacteriol. 1995, 177, 235-237.
(62) Kooi, M.; Besseling, E.; Kroeze, C.; van Wezel, A. P.; Koelmans, A. A. Erratum to: Modeling the Fate and Transport of Plastic Debris in Freshwaters: Review and Guidance. In Freshwater Microplastics: Emerging Environmental contaminants?; Wagner, M., Lambert, S., Besseling, E., Biginagwa, F. J., Eds.; In The Handbook of Environmental Chemistry/Founded by Otto Hutzinger; Editors-InChief: Damià Barceló, Andrey G. Kostianoy; Springer Open: Cham, 2018; Vol. 58, p E1.

(63) Pluskota, A.; Horzowski, E.; Bossinger, O.; von Mikecz, A. In Caenorhabditis elegans nanoparticle-bio-interactions become transparent: silica-nanoparticles induce reproductive senescence. PLoS One 2009, 4, No. e6622.

(64) Duis, K.; Coors, A. Microplastics in the aquatic and terrestrial environment: sources (with a specific focus on personal care products), fate and effects. Environ. Sci. Eur. 2016, 28, 2.

(65) Haegerbaeumer, A.; Mueller, M.-T.; Fueser, H.; Traunspurger, W. Impacts of Micro- and Nano-Sized Plastic Particles on Benthic Invertebrates: A Literature Review and Gap Analysis. Front. Environ. Sci. 2019, 7, 17.

(66) Adam, V.; Yang, T.; Nowack, B. Toward an ecotoxicological risk assessment of microplastics: Comparison of available hazard and exposure data in freshwaters. Environ. Toxicol. Chem. 2019, 38, 436447.

(67) Lenz, R.; Enders, K.; Nielsen, T. G. Microplastic exposure studies should be environmentally realistic. Proc. Natl. Acad. Sci. U.S.A. 2016, 113, E4121-E4122.

\section{NOTE ADDED AFTER ASAP PUBLICATION}

This paper was published ASAP on January 14, 2020, and reposted on January 17, 2020 with a revised abstract graphic. 